\title{
10 CHINA: WHERE WILL THE CONTEST FOR REGIONAL LEADERSHIP END?
}

\section{Yiping Huang and Xinpeng $\mathrm{Xu}$}

\section{The return of a world power}

Economic growth in China in the last two decades has been most spectacular. With annual growth of about 9 per cent, China has attracted tremendous attention worldwide. Few would dispute that China is now one of the important engines of growth in the world economy.

Perhaps less well known is the fact that China had been the most powerful and biggest state in the world for nearly two millenniums. Until the nineteenth century, China's share of world GDP was higher than that of all of Western Europe combined. China accounted for about a quarter of the world GDP from the beginning of the first millennium and has remained as dominant player until Western Europe caught up in the midnineteenth century (Figure 10.1). Western Europe started its rapid catchup with China from the fifteenth century and surpassed China in the eighteenth century. In fact, China was a victim of its own success, as it indulged itself in its technological prowess and demonstrated no interest at all in the rapid technological development of Western Europe since the fifteenth century. According to Angus Maddison: 
Figure 10.1 Shares of world GDP, 1000-2030(1990 international \$, per cent)

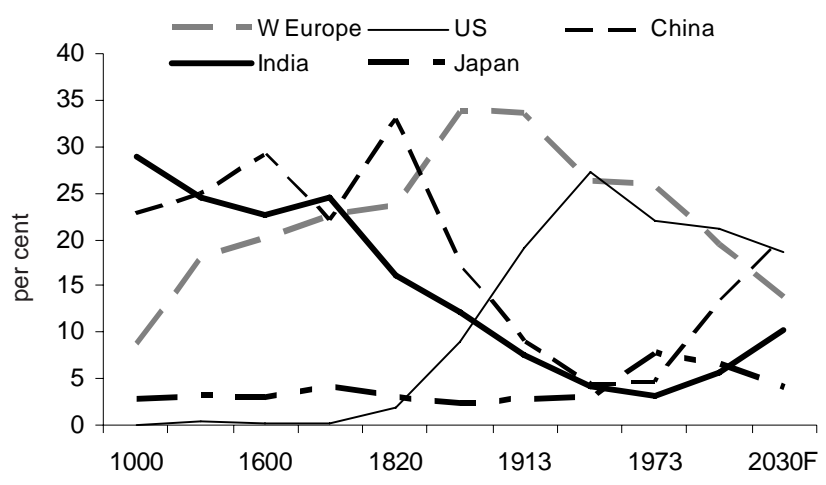

Source: Maddison A., 2002. The World Economy: A Millennial Perspective, OECD Development Centre, Paris.

A British mission in 1793 tried to open diplomatic relations and demonstrate the attractions of western science and technology with 600 cases of presents (including chronometers, telescopes, a planetarium, chemical and metal products). The official rebuff stated 'there is nothing we lack - we have never set much store on strange or ingenious objects, nor do we want any more of your country's manufactures'. China did not start establishing legations abroad until 1877 (Maddison 2002:117).

China had become an increasingly inward-looking economy. Even worse was a whole series of internal rebellions such as the Taiping rebellion (18511864). Plagued with war and foreign intrusion since 1840s, China's share of world GDP had declined sharply from almost one-third to about five per cent (see Figure 10.1). During the same period, western economies experienced extraordinary expansion as a result of the industrial revolution.

It is not just the economic size of China that was bigger than that of the Western Europe-per capita GDP in China had also been higher until the sixteenth century (Maddison 2002). Thereafter, Europe took the lead and China started to lag behind (Figure 10.2). China's per capita GDP in the early 1950s was less than its 1820 level. In sharp contrast was the 


\section{Figure 10.2 Comparative GDP per capita China and Western}

Europe, 50-1998 (1990 international \$)

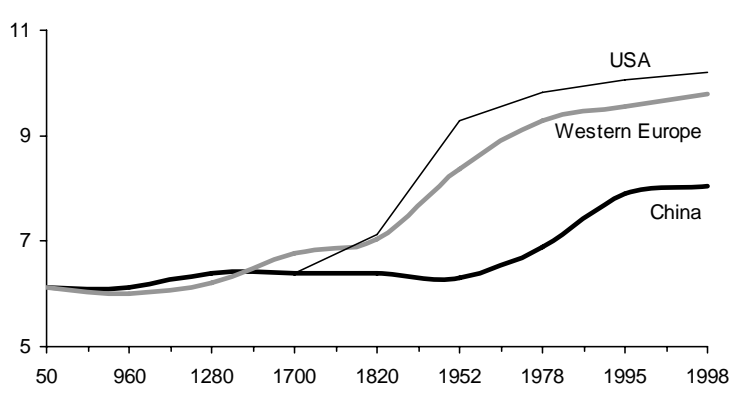

Note: The vertical axis is in natural logarithm.

Source: Maddison, A. 2002. Chinese Economic Performance in the Long Run, OECD

Development Centre, Paris. The World Economy: A Millennial Perspective, 1998, OECD

Development Centre, Paris.

tripling of both Western Europe's and Japan's income per capita and an increase of more than eight-fold in the US GDP per capita during this period. When other countries in the world were charging ahead, China was in decline. The three decades since 1950s saw a five-fold increase in Japan's per capita income, from $\$ 2,351$ (1990 international dollars) to $\$ 11,581$ (1990 international dollars), while China's per capita just falls short of doubling under central planning (Maddison 1998).

China started to emerge from its century-long decline only after the economic reforms and opening up that have taken place since 1979. China is now established as an engine of growth in East Asia and beyond, through its rising share in regional production and trade, and its close structural links with other economies in the region. The economic size of China measured in terms of current output has been rising, and the Chinese economy is now almost one-third of the size of that of Japan-even based on market exchange rate calculated output measures (Figure 10.3). The contrast is even more striking if the comparison is based on purchasing power parity (PPP) calculated output measures, by which China has already surpassed Japan and, after 1993, become the second largest economy in the world (Figure 10.4). With growth rates averaging close to 10 per cent 


\section{Figure 10.3 China and East Asia in the world economy, output share, 1980-2003 (per cent)}

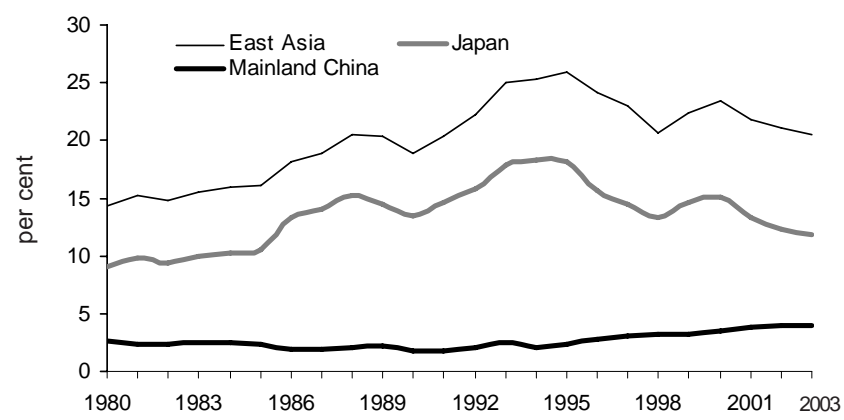

Notes: Shares of aggregate GDP based on current market exchange rate in US dollars. East Asia 10 includes Japan, South Korea, mainland China, Taiwan, Hong Kong, Thailand, Malaysia, Indonesia, Singapore and the Philippines.

Sources: Drysdale P. and X.P. Xu, 2004. 'Taiwan's role in the economic architecture of East Asia and the Pacific', Pacific Economic Papers No. 343, Australia-Japan Research Centre, The Australian National University, Canberra.

Figure 10.4 China and East Asia in the world economy, output share, 1980-2003 (per cent)

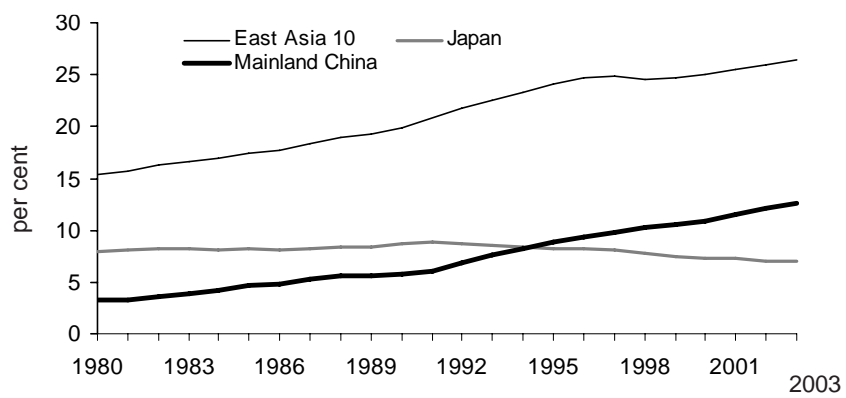

Notes: Shares of aggregate GDP based on purchasing power parity (PPP) valuation of country GDP. East Asia 10 includes Japan, South Korea, mainland China, Taiwan, Hong Kong, Thailand, Malaysia, Indonesia, Singapore and the Philippines.

Sources: Drysdale P. and X.P. Xu, 2004. 'Taiwan's role in the economic architecture of East Asia and the Pacific', Pacific Economic Papers No. 343, Australia-Japan Research Centre, The Australian National University, Canberra. 
per annum since 1990, China has been, and is expected to continue to be, the most important new player in the regional and the world economy.

China's global significance is seen almost everywhere. During the last couple of years, China contributed roughly one-third of global economic growth. It accounts for about 20 per cent of world's total labour-intensive exports and more than 60 per cent of total Asian electronic exports. Large volumes and low prices of such products earned China reputations such as 'a global manufacturing centre' or 'exporter of global deflation'. Many also regard the 'China factor' as the key driving force behind skyrocketing commodity prices.

China has even become an important force in the international capital markets, despite China's own capital account controls. Renminbi exchange rate policy is a key factor influencing global currency markets. In early 2007, corrections of the domestic A-share markets sent shockwaves across global equity markets.

\section{Can China's rapid growth continue?}

According to Maddison's prediction, China will overtake the United States to become the world's largest economy by 2030 . Whether or not such prediction will materialise depends on China's ability to translate its recent success into sustainable growth of output in the future. To answer this question, we employ a simple yet conventional approach, that is, a growth accounting approach, to look into this important question. According to growth accounting theory, economic growth depends on an accumulation of factors, mainly capital stock and labour, and increase in total factor productivity (TFP). In mathematical form, the growth accounting equation is

$$
y=\delta+\alpha k+(1-\alpha) l
$$

where $y, \delta, k$, and $l$, represent, growth in output, total factor productivity, capital stock and labour, respectively. $\alpha$ refers to the share of capital in total output or, technically speaking, elasticity of output with respect to capital. We assume $\alpha$ to be 0.4 , which is somewhat higher than the usual 0.35 as in Bosworth and Collins (2003). We believe that capital may be more important (productive) in a large developing country like China 
where labour is relatively abundant. Assuming production technology exhibits constant return to scale, we obtain $(1-\alpha)$ as the share of labour in total output or elasticity of output with respect to labour. Mathematically, TFP is a residual, by subtracting contributions of capital and labour from output growth.

It is a well-known fact that data for China's agriculture and service sectors are difficult to come up with and even there are some estimates around they are prone to criticism. Together, China's agriculture and service sectors account for about one-third of the total national output. Interestingly, agricultural sector has been growing slowly while the services sector has developed rapidly in the past decade. For a country that is experiencing rapid industrialisation, it may not be too unreasonable to assume that on balance China's agriculture and services sectors grow at the same rate as that of the manufacturing sector. And by such an assumption we can focus on the manufacturing sector where relatively high-quality data are available.

Table 10.1 shows a growth accounting decomposition for China's manufacturing sector, with detailed construction of capital stock and labour working hours in $\mathrm{Wu}$ and $\mathrm{Xu}$ (2004). In the past two decades, China's capital stock grew at a rate of about 10 per cent per annum, contributing to output growth by about 4.3 per cent. We expect this trend to continue for two reasons. First, the returns to investment will remain high as China carries out its reform in the state-owned sector and the government sector, which boosts up productivity. It will not run into diminishing returns for a long period of time as both labour force participation and productivity are increasing. Second, the accumulation of capital in China will not run into the 'financing constraint' as China has the world's highest saving rate. More importantly, China's accession to the World Trade Organisation delivers a significant long-term commitment to economic liberalisation, which has attracted a huge inflow of foreign capital, already averaging around US\$45 billion annually over the past few years (Woo 2001).

Growth of labour working hours has been low in the last decade, thanks to the reform in state-owned enterprises that shed away huge number of redundant workers. The private sector will continue to expand and become the major sector that provides employment. Given the huge surplus workers 


\section{Table 10.1 Growth accounting for Chinese manufacturing sector, 1980-2000 (per cent)}

\begin{tabular}{ccccccc}
\hline & $\begin{array}{c}\text { Growth of } \\
\text { output }\end{array}$ & $\begin{array}{c}\text { Growth of } \\
\text { capital }\end{array}$ & $\begin{array}{c}\text { Growth of Contribution } \\
\text { labour }\end{array}$ & $\begin{array}{c}\text { Contribution } \\
\text { of capital }\end{array}$ & $\begin{array}{c}\text { Total factor } \\
\text { of labour }\end{array}$ & productivity \\
$1980-1991$ & 8.8 & 10.7 & 5.5 & 4.3 & 3.3 & 1.2 \\
$1992-2000$ & 9.3 & 10.6 & -0.1 & 4.3 & - & 5.0 \\
\hline
\end{tabular}

Note: Estimation in this table assumes output elasticity of capital and labour at 0.4 and 0.6 , respectively.

Source: Wu Harry X. and Xinpeng Xu 'A fresh scrutiny of productivity performance in Chinese manufacturing, 1952-2000’. Asia Pacific Productivity Conference, 2004

Conference, Brisbane.

in China, in both rural and urban sectors, we expect that labour working hours will grow at least by 2 per cent per annum, contributing to output growth by 1.2 per cent.

The above findings on productivity growth in China are consistent with the results of some recent analyses. Bosworth and Collins (2007), for instance, found that between 1993 and 2004 total factor productivity contributed more than 40 per cent of GDP growth (about 4 percentage points) or 56 per cent of industrial production growth (about 6.2 percentage points).

We are more optimistic about China's total factor productivity growth than some researchers. We think there is great upside potential for TFP to grow. Maintaining a 2.5 per cent growth annually should be a conservative estimate, given that the TFP growth in the past decade has been increasing at an average of 3.2 per cent per annum.

Recent studies by development economists have identified three factors, namely openness, institutions and geography, as fundamental forces that drive economic growth (Rodrik et al. 2002). It is China's commitment to liberalisation, reform and openness that draws it politically as well as economically closer to the world's major centres of economic power in North America, Europe and East Asia and that provides the foundations for substantial and sustainable economic growth at home.

Specifically, there are several factors that point to this upside potential. First, continued institutional reform, especially after China's accession to 
the WTO, would promise higher quality of institutions in China, which would lead to higher TFP. According to Rodrik and Subramanian (2004), China has been performing very well (above the 'regression line') in the past two decades given its relatively low quality of institutions and will 'regress' back to normal growth rates warranted by its quality institutions. This may be the case if reform in China stalls. But we have seen rapid improvement in the reform of previously highly protected sectors, for example privatisation of state-owned enterprises and gradual removal of monopoly powers in sectors like electricity, transportation, telecommunication, wholesale and retail, and banking, etc. We expect the quality of institutions in China will continue to improve.

Second, China will continue to take advantage of the technological backwardness as it moves towards the frontier of world technology. Even though China is already a major player in the world economy, its GDP per capita is still well below US\$2,000, which is not only substantially lower than those in the advanced economies but also below those in most of its East Asian neighbours. Experiences of other rapidly industrialising economies suggest that, when an economy is far away from the frontier of world technology, it is easier for it catch up by copying existing technologies. In this regard, integration with the international market through trade and investment provides golden opportunities. Productivity gains flow from trade gains through cheaper imports and their impact on import and export sector efficiency and also from the technology spillover through foreign investment.

Third, China's high levels of human capital will be an important source of TFP growth. Chinese have traditionally paid attention to human capital development. The return to schooling has been increasing, compared to the case in the 1980s. More investment in human capital has now been observed in coastal cities and will soon spread to other part of the countries, which will lead to higher accumulation of human capital. Moreover, as incomes rise and opportunities grow within China, more overseas educated people will return to China, in contrast with the case in the 1980s when the return to education was low and many young Chinese left for the United States and Europe, which once caused a 'brain drain' alarm.

Taken together, we suggest that an annual growth of 8 per cent should be sustainable for China for a significant period of time. With this annual 
growth rate, China would be able to double its income in every nine years. While the above is our base case scenario, it is by no means a guaranteed outcome. In fact, the Chinese economy still faces numerous risks and problems, which include unemployment, income disparity and political uncertainties. The biggest risk, however, lies in inefficiency of capital allocation.

Inefficiency of capital allocation is reflected in a number of ways. Functioning of the financial intermediation remains sub-optimal. In the banking sector, for instance, while the authorities and the banks recently stepped up efforts in improving their competitiveness, progress so far appear to be limited. Though average non-performing (NPL) ratio in the banking sector declined to 7.2 per cent at the end of 2006 from 23 per cent at the end of 2002 (Figure 10.5), overall the NPL outlook is not optimistic. First, many recently revealed bank scandals raise the question about the size of hidden 'black holes' in the state banks. Second, while most commercial banks have implemented the international standard fivecategory loan classification system, definition for each category was actually left to individual commercial banks. And, third, the fact that about half of the existing outstanding loans, which is about 65 per cent of GDP, was extended during the past three to four years certainly points to potential risks going forward. This is particularly the case as we expect the government continues to tighten and the macroeconomy gradually takes a downturn.

Meanwhile, capital is substantially under-priced in China, which leads to further problems of inefficiency. In 2006, for instance, nominal GDP increased by close to 14 per cent, but the one-year base lending rate was only 6.11 per cent (which increased to 6.39 per cent in March 2007 after another rate hike), and five-year government bond yield was well below 4 per cent. A number of factors are responsible for capital being too cheap in China, including a high savings ratio in relation to low consumer confidence, capital account controls restriction capital outflows, inefficient banks and capital markets, and an undervalued exchange rate encourage capital inflows.

Therefore, resolving the capital inefficiency problem requires systemic policy actions. And this is probably the biggest hurdle that China faces in sustaining its rapid growth. 


\section{Figure 10.5 Average non-performing loan ratios in the Chinese banks, 2002-2007 (per cent)}

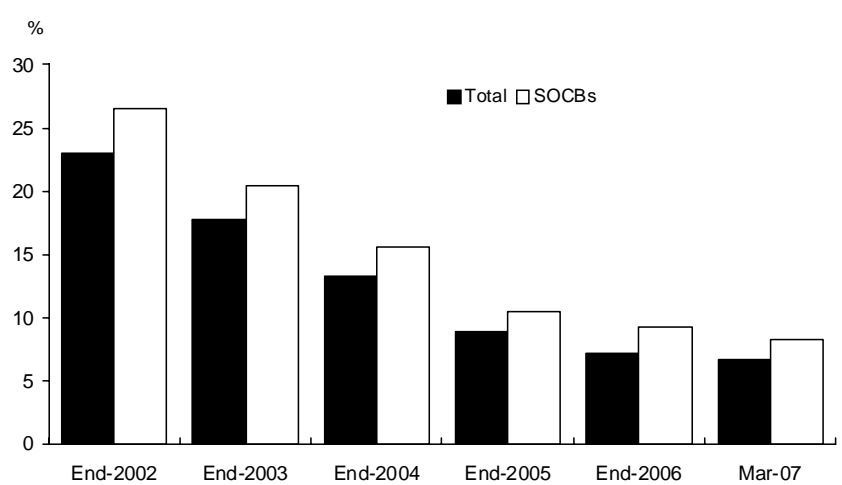

Source: China, China Banking Regulatory Commission, Beijing.

\section{Economic impacts on the region}

Even though China is still at the early stage in its re-emergence, its impacts on the global economy, especially the regional economy, are already phenomenal. In fact, today China is one of the hottest subjects of economic discussion in almost every economic centre around the world. China's global influences are primarily reflected in the following areas-strong demand for commodities, extraordinary expansion of exports, rapid growth of foreign direct investment (FDI) and choices of exchange rate policy.

Global commodity prices rose significantly in recent years and one of the major driving forces was very strong demand in China. In 2003, China accounted for large shares in world consumption of a number of commodities-33 per cent in coal, 23 per cent in steel, 20 per cent in aluminium, 10 per cent in alumina, 11 per cent in copper (Figure 10.6). In some markets where China's overall shares are still small, its contribution on the margin is already quite significant. For instance, while China's consumption of crude oil was only about 8 per cent of the world total in 
Figure 10.6 China's share of world consumption/production of metal products, 2003 (per cent)

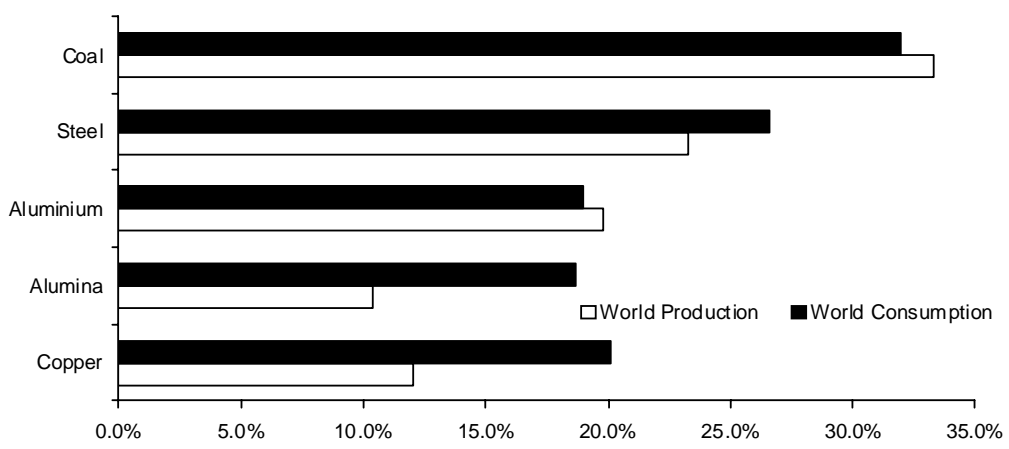

Source: Citi Investment Research estimates using data from World Bureau of Metal Statistics, CRU Group Reports, London Metals Exchange, British Petroleum, Tex Report and China Nonferrous Metals Industry.

2004 , it contributed about half of the incremental demand in the world crude market.

China's extraordinary commodity consumption, which is disproportional to its economic size, was at least in part related to the over-investment problem. Therefore, there is a question if the current momentum can be sustained over time as China slows the pace investment expansion to achieve more sustainable growth. However, the expected rapid growth of the economy, continued industrialisation process and new waves of urbanisation in the coming decades are likely to underpin strong demand for commodities in China. In fact, commodity producers in Latin America, Australasia, Middle East, Central Asia and Africa have made macroeconomic development in China as a key factor in their corporate planning.

The impacts of Chinese economic expansion on other Asian economies have been even clearer. Economic recoveries of most Asian economies from 2002 were led by export growth. Intra-regional trade expanded rapidly in East Asia, primarily because of increasing roles played by China (Figure 10.7). Today, China is already the largest export market for Korea and Taiwan 
Figure 10.7 Growing intra-regional trade in East Asia, 1998-2006 (US\$ billion)

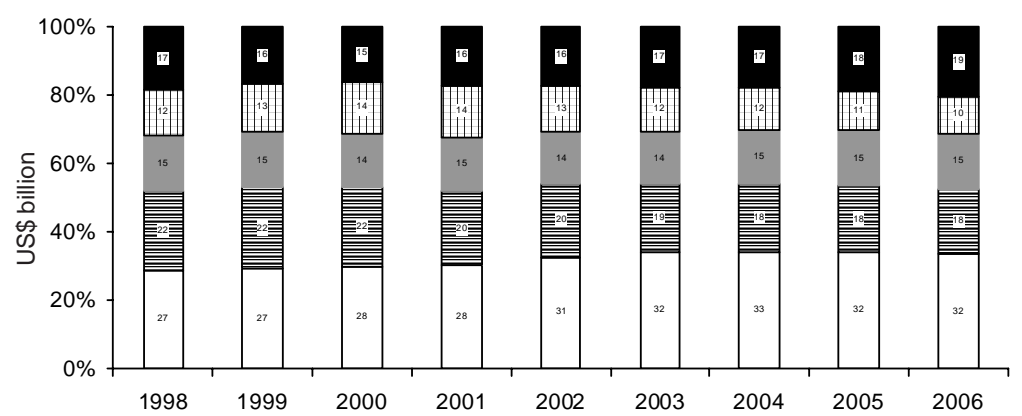

$\square$ East Asia ex. India and Singapore 国US EU $⿴$ J Japan $\square$ Rest of the world

Note: Asian economies here exclude China and Japan.

Source: CEIC Data, Hong Kong and Citigroup estimates in Citi Investment Research, Asian Economic Outlook and Strategy, Hong Kong (various issues).

and is one of the most important export markets for many other Asian economies including Japan. Japan's exports to China have also increased significantly since 2001, while its total exports only rose 25 per cent during the same period. China has been a true engine of growth for the region.

China's growing importance in regional and global trade also increased the openness of its own economy. The share of exports in GDP climbed from 22 per cent in 2001 to nearly 35 per cent in 2004, a path that is very similar to those travelled by other East Asian economies in earlier years. Naturally, a more open China and, particularly, rapid rise of Asian exports to China led to greater degree of intra-regional trade in Asia. More interestingly, changes in China in recent years have shifted gradually the supply chains in some industries, especially in the tech sector. Many Asian economies, including Japan, Korea, Taiwan, Singapore, Malaysia and Philippines, specialise in production of electronic and technology products. In the past, these economies exported large volumes of tech products to America and Europe. In recent years, however, China begins to dominate labour-intensive segment of the technology industries. As a result, those 
other Asian economies export relatively more sophisticated intermediate goods to China and then China exports finished goods to America and Europe.

One side-effect is the rapid increase in China's bilateral trade surpluses with the United States and Europe (Figure 10.8). In fact, the growing trade imbalance between China and the United States has become a serious political issue. According to the Chinese statistics, China's bilateral trade surplus against the United States rose from US\$28 billion in 2001 to US $\$ 80$ billion in 2004, a net increase of US\$52 billion. ${ }^{1}$ Similarly, China's trade surplus against the European Union economies increased US\$30 billion during the same period. However, China's trade balances fell by US $\$ 23$ billion against Japan and US $\$ 68$ billion against the other East Asian economies. In fact, China's overall trade balances were reasonably stable, fluctuating between US\$22 billion and US\$32 billion, during those years. Thus, it would be too simple-minded to argue that deterioration of the US bilateral trade relation with China was caused by unfair terms of trade such as China's currency peg.

Figure 10.8 China's changing bilateral trade balances with USA, European Union, Japan and East Asia, 2001-2006 (US\$ billion)

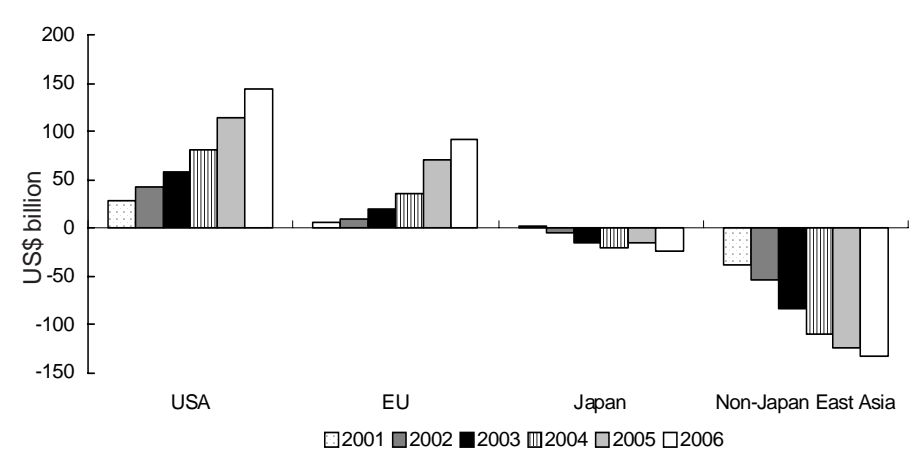

Sources: CEIC Data, Hong Kong and Citigroup estimates in Citi Investment Research, Asian Economic Outlook and Strategy, Hong Kong (various issues). 
Figure 10.9 FDI inflows to China: total amount of utilised FDI and its share in gross capital formation, 1984-2004 (US\$ billion and per cent)

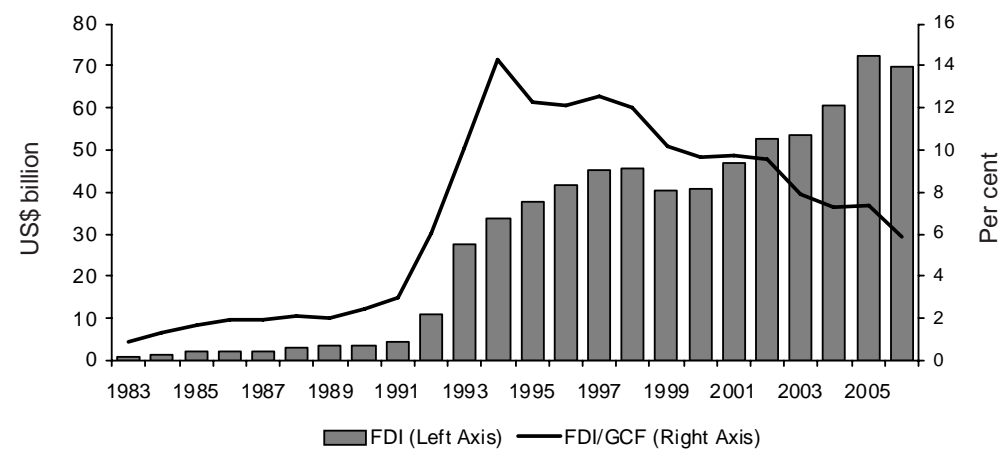

Sources: CEIC Data, Hong Kong and Citigroup estimates in Citi Investment Research, Asian Economic Outlook and Strategy, Hong Kong (various issues).

The situation of FDI is perhaps more complicated. In the short-term, especially right after China's WTO entry, competition between FDI going into China and that into other Asian economies was quite clear. Some investors even reportedly closed their operations in Philippines, Thailand and Malaysia to move to China. However, taking a longer-term perspective, the benefits of growing Chinese markets to other Asian economies are clear, especially if they can integrate into a unified market (see Farrell and Pangestu, Chapter 8 for an alternative view).

Finally, choices for China's exchange rate policy reform going forward is probably one of the most important factors affecting the global financial markets today. For example, the offshore non-deliverable forward (NDF) market moves quickly following news flows and policy statements (Figure 10.10). On July 21, 2005, the Chinese authorities finally gave up the seven-year old de facto peg to the US dollar and introduced the managed float system with reference to a basket of currencies. The new regime turned out to be much less flexible than many expected when the reform was 
Figure 10.10 Expected revaluation of the Chinese currency within one year at the non-deliverable forward market, 20022007 (per cent)

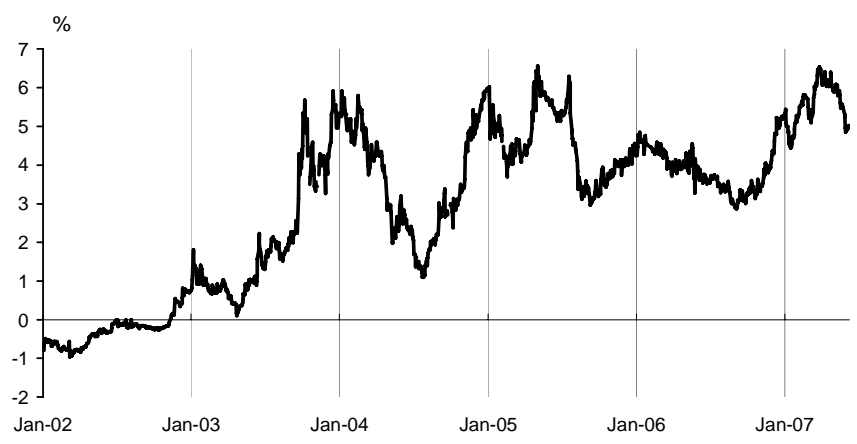

Sources: CEIC Data, Hong Kong and Citigroup estimates in Citi Investment Research, Asian Economic Outlook and Strategy, Hong Kong (various issues).

introduced. However, by the end of March 2007, renminbi had appreciated by 6.8 per cent against the dollar or by half that on real effective exchange rate terms. Going forward, renminbi is likely to maintain a steady appreciation trend given rapidly accumulating foreign reserves, persistent trade surpluses, resultant excess liquidity in the domestic system, and growing external pressures for currency appreciation from the major trading partners. However, drastic currency appreciation still looks unlikely as China's policymakers are still deeply concerned about the potential adjustment costs in terms of jobs and growth.

Reform of the Chinese exchange rate policy was at least in part responsible for a turning point in the global currency markets. In 2003 and 2004, real depreciation of the US dollar was accompanied by real appreciation of the euro and the Japanese yen. The year 2005 represented a turning point when the US dollar, euro and yen all depreciated in real terms. The currencies which shouldered the burden of adjustments are those from emerging Asian economies. This new trend continued in 2006 and is likely to remain in 2007 . The fact that the turning point in global exchange rates occurred in the same year as China's exchange rate policy reform was 
Figure 10.11 Changes in real effective exchange rates, 2003-2007 (per cent)

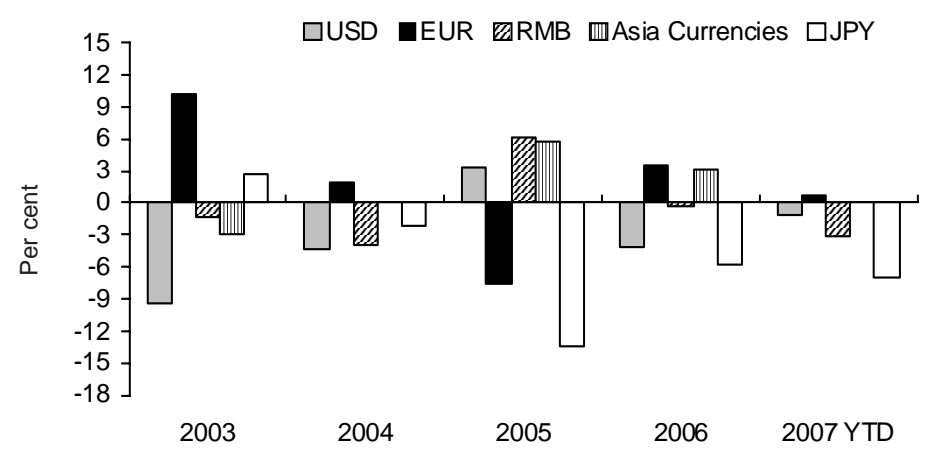

Source: Citigroup estimates in Citi Investment Research, Asian Economic Outlook and Strategy, Hong Kong (various issues).

probably not accidental. The renminbi exchange rate has already become an important benchmark for Asian monetary policymakers in managing their own exchange rate policies.

\section{Prospects for a China-Japan partnership}

China's former paramount leader Deng Xiaoping, the architecture of China's reform policy, once laid down an important strategy for new generations of the Chinese leaders-keeping low profile in international affairs and developing the economy. And, in this spirit, the former President Jiang Zemin coined the term 'peaceful ascendancy'.

But ascending peacefully is by no means an easy task. An increasingly powerful China inevitably causes some uneasiness among its small neighbours. But most importantly, it makes the United States, the only super power of the world today, feel under threat. China bashing is a frequent phenomenon in the United States, on issues of human rights, arms sales, intellectual property rights, trade imbalances and exchange rate policy. Most analysts expect China to overtake the US economy within 
the next forty years. But in reality, there is still a very long way to go before China can challenge the United States on any real terms.

In the coming decade or so, competition is likely to concentrate in the East Asian region, especially in the race for regional leadership. As the region's most important economic power, Japan has been a regional leader for several decades, especially on certain economic initiatives, such as the APEC. But Japan's leadership role suffers from a number of drawbacks. First, as on most foreign policy issues Japan follows closely the US position, so it acts more like a branch office of the United States rather than an independent regional leader. Second, Japan's economy was stagnant for more than a decade, reducing its economic influence in the region. And, finally, Japan still suffers from its own war-time legacy issues, especially in dealing with its close neighbours such as China and Korea.

This was probably why, from time to time, Japan exercised leadership role from behind, which led to the prominence of the Japan-Australia relationship in the regional affairs in the 1980s and early 1990s. But by late 1990s, it had become clear that even such a leadership pattern was no longer sustainable. This was in part because of Japan's reduced influence and in part due to deeper integration among ASEAN economies. In addition, Australia drifted away from the centre of Asian affairs.

During the first half of the 21st Century, accommodating the rising China is likely the most important challenge for the East Asia region. Before the middle of that period, China will probably overtake Japan as the region's largest economy. While the relationship between the two regional powers will be tricky, the China-Japan partnership is the key to the continuation of prosperity in Asia.

It is not difficult to predict China's growing economic importance to the region. For instance, China is now already Japan's largest trading partner. But when it comes to exercising a leadership role in Asia, China also faces certain constraints, including historical problems with India, Korea and Vietnam. Most importantly, China's Communist Party-dominated authoritarian political system leaves many doubts and suspicions among its neighbours, especially in regard to predictability of its behaviour in regional and global affairs. Thus, political reforms will be critical for China's eventual ascendancy to a global leadership role. 
For the time being, the China-Japan partnership plays a very important role. Given the recent deadlocks in the Sino-Japanese relations, especially the mass protests against Japan in major Chinese cities such as in 2005, it is difficult for a close partnership to emerge between the two any time soon. Indeed, numerous conflicts or disagreements exist between the two countries, including

- disagreements over Japan's recognition of its wartime crimes, especially in relation to China's continuous demand for an apology from Japan, the Japanese Prime Minister's annual visits to Yasukuni shrine and controversial revisions of textbooks in Japan

- claims of sovereignty by both countries over islands, called 'Senkaku' by the Japanese and 'Diaoyu' by the Chinese, and the rights to exploit natural gas resources in the East China Sea

- Japan's demand to become a permanent member of the expanded Security Council of the United Nations, which is opposed by China

- the US-Japan security understandings that refer to the stability of the Taiwan Strait as key interests for the two parties. In response to this, China passed its anti-secession law in 2005 allowing the government to use military force as a last resort to achieve reunification.

Pessimists may conclude that it would be impossible for the two countries to work together. But we easily forgot that there were times in the history when they worked very closely with each other, first time about two thousand years ago during the Tang Dynasty and the most recent time in the 1980s when Hu Yaobang was the General Secretary of the Communist Party. What it takes is political leaders' vision and courage.

Of all the difficult issues currently facing the two countries, the most challenging one is the Taiwan issue. In a worst-case scenario, a war between China and Japan may be possible-once China launches a war against Taiwan, Japan is obliged to help the United States who will probably help defend Taiwan. But judging from the recent developments across the Taiwan Strait, we believe that military action is certainly not inevitable.

It is a long shot to call for a China-Japan partnership. But with the region's two most important economies constantly in conflict with each other, it is difficult to expect an effective framework for regional 
development and cooperation. The visits to China by Japanese Prime Minister Abe in late 2006 and to Japan by Chinese Premier Wen in early 2007 generated some hopes for establishing more normal working relations between the two countries. But only history can tell how this relationship will evolve, which will have significant implications for the region and the world.

\section{Notes}

1 The numbers cited here are for illustration purpose only, as US officials would argue that the Chinese official statistics substantially underestimate China's bilateral trade surpluses against the United States. The differences between the Chinese and American data are caused mainly by treatment of Chinese re-exports to the United States through Hong Kong.

\section{References}

Bosworth B., and Collins, S., 2003. The empirics of growth: an update, Brookings Institution, Washington, DC (unpublished).

—, 2007. Accounting for growth: comparing China and India, NBER Working Paper Series 12943, National Bureau of Economic Research, Cambridge, MA.

Drysdale, P. and Xu, X.P., 2004. Taiwan's Role in the Economic Architecture of East Asia and the Pacific, Pacific Economic Papers No 343, AustraliaJapan Research Centre, The Australian National University, Canberra. Maddison, A., 1998. Chinese Economic Performance in the Long Run, OECD Development Centre, Paris.

- _, 2002. The World Economy: a millennial perspective, OECD Development Centre, Paris.

Rodrik, D., Subramanian, A. and Trebbi, F., 2002. Institutions rule: the primacy of institutions over geography and integration in economic development, NBER Working Paper 930, National Bureau of Economic Research, Cambridge, MA.

- 2004. Why India can grow at 7 per cent a year or more: projections and reflections, IMF Working Paper No. 118, International Monetary Fund Washington, DC. 
Woo, W.T., 2001. 'Recent claims of China's economic exceptionalism: reflections inspired by WTO accession', China Economic Review, 12(2/ 3):107-36.

Wu, H.X and Xu, X.P., 2004. 'A fresh scrutiny of the productivity performance in Chinese manufacturing in 1952-2000', Asia Pacific Productivity Conference, 2004 Conference, Brisbane, 14-16 July.

\section{Acknowledgments}

This is a revised version of the paper presented at the seminar 'Japan's Future in East Asia and the Pacific - In Honour of Professor Peter Drysdale', on 19 August 2004 hosted by The Australian National University. The authors, both former students of Peter, are especially grateful for his guidance, supports and friendship over the years. Views expressed in this article are those of the authors and do not necessarily represent those of the authors' affiliated institutions. 